\title{
ANALYSIS OF CONNOTATION WORDS IN THE JAKARTA POST ONLINE HEADLINE NEWS
}

\author{
Eva Nurul Candra ${ }^{1}$ and Elyza Martiarini ${ }^{2}$ \\ Department of English Education, School of Language and Art \\ University of Indraprasta PGRI \\ evanurul.chandra@unindra.ac.id elyza.martiarini@unindra.ac.id
}

\begin{abstract}
This research aims to analyse connotation words in the Jakarta Post online headline news and to find the positive and negative connotation of those online headline news. Qualitative method and descriptive analysis are applied in this research. There are 30 headline news of data sources. The result of the research shows that 46,66 \% of the 30 headline news online use positive connotation words and 53,33\% of them use negative connotation words in the news. And it also shows that an online newspaper headline might evoke different feelings and emotions to the readers by using the connotation words. This finding implies that the most connotation words used in the headline news is negative connotation.
\end{abstract}

Key words : connotation words, the Jakarta Post online headline news

\begin{abstract}
Abstrak
Penelitian ini bertujuan untuk menganalisis kata-kata konotasi dalam berita utama Jakarta Post secara online dan untuk menemukan konotasi positif dan negatif dari berita utama online tersebut. Metode kualitatif dan analisis deskriptif diterapkan dalam penelitian ini. Ada 30 berita utama sebagai sumber data. Hasil penelitian menunjukkan bahwa 46,66\% dari 30 berita utama online menggunakan kata - kata konotasi positif dan 53,33\% di antaranya menggunakan kata - kata konotasi negatif dalam berita. Hasil tersebut juga menunjukkan bahwa judul surat kabar online dapat membangkitkan perasaan dan emosi yang berbeda terhadap pembaca dengan menggunakan kata-kata konotasi. Temuan ini menyiratkan bahwa kata-kata konotasi yang paling banyak digunakan dalam berita utama adalah konotasi negatif.
\end{abstract}

Kata kunci: kata konotasi, berita utama Jakarta Post online

\section{INTRODUCTION}

Nowadays online news articles might be said to be the basis of communication as they are the main source which delivers most up-to-date news on social life, culture, politics, etc. to the audience. The language of this type of media (news articles) is characterised by publicistic register which is different from other registers both in writing strategies and functions. Publicity register, therefore, is considered to be the means of mass communication. The common functions of the publicistic register are to inform, persuade, reflect the state of the society and form people's attitudes. It means that information in publicistic articles has to be up-to-date, precise and, of course, informative. The most common features of publicistic register are: clarity and accuracy of the language, generally known terms, periphrastic expressions and journalistic clichés, whereas the emphasis is on situational and cultural context. Linguistically, this register is characterised by positive or negative 
evaluative adjectives (which work for persuasive function), impersonal expressions, emotionally marked language, euphemisms, metaphors, phraseological units, metonymic, short sentences, active voice, present tense, etc. (Bitinienè, 2007:59). Publicistic language is nowadays characterised by commentaries and by imposing personal opinion. What concerns online articles, the requirements for them are, in fact, similar to those of newspaper articles, McNair (2009:75).

However, the language of online texts has been affected by readers' fast lives. Consequently, the text and the language has been transformed by the content of the articles which are extremely simplified and rather shallow with the main objective to provide information, advertise; some deeper analysis, however, is left overboard. As a result, the role of headlines of online news articles is transformed: they have to actually "attack" the reader, not just to attract their attention (Marcinkevičienè, 2010). Online texts are created on the basis of inverted pyramid style which ensures that the most important and relevant information is delivered to the reader at the very beginning, by the headline in particular (Rich, 2010:47).. This writing method is valued since the reader can leave the text at any point and still understand it, which is extremely relevant with modern-day online readers, or skimmers. Craig (2004) stated that headline writing, thus, is the craft which makes news articles or even newspapers or magazines either successful among the audience or not.

On the basis of language used in the headline online news, it sometimes uses very short words to make an impact. These are sometimes violent words e.g. Thugs battle. A thug is a violent person and a battle is a fight (it is a noun and a verb). This headline could also read Some thugs have been fighting, however, this does not have the same impact as the short headline itself. Related to the language impact used in the headline online news, it will bring the readers to the meaning semantically both denotative and connotative features. Denotative will ease the reader to the real meaning as stated in the dictionary, whereas connotative meaning will bring them to the variety of thinking critically. Connotation is an important and omnipresent source of language enrichment in what headlines newspaper concern. Headlines are important in their own right, because they are the first text that a newspaper reader sees when buying and reading the paper. They employ a range of creative language devices to produce short attentiongetting, highly memorable texts, and have the capacity to encapsulate an entire story in a few words.

Based on the discussion above, there are two main questions in this research, as follow : 1) How is the language used in the Jakarta Post headline news online? 2) What is the type of connotation words that dominantly arise in the Jakarta Post headline news online?

\section{Meaning of Headline News}

Headline writing is the craft which makes news articles or even newspapers or magazines (in this case online headline news ) either successful among the audience or not. Headline writers, however, very often are not those who write articles (Marcinkeviciene, 2008: 176). The popularity and readability of the article quiet often depends on the headline which is a representative part of the article and can, therefore, be consider as the most important part of publicistic article ( Rich, $2010: 259$ ) it is possible to say that headlines are the "medium" which communicates and interacts 
between the author and the reader ( Bitiniene, $2007: 62$ ).

Headlines have very specific thematic functions: they usually express the most important topic of the news items (Dijk, 1985 : 69). In other words, headlines represent the main ideas of the articles in a condensed form, thus, very ofren "a forcible and informative element" is included so that the headline could intrigue the reader (Bitiniene, 2007:65) and capture his/ her attention (Rich, 2010 : 259). Hence, two types of headlines could be identified (Marcinkevičienè, 2008:176):

1. subject headline (the one which defines the subject of the article),

2. thesis headline (the one which includes the main thesis of the article and, therefore, allows to present a subjective opinion).

Linguistic structures used in headlines are specific (Saxena, 2004 : 44-50; Rolnicki et al., 2007):

1. simple and specific words are the most important requirement in headlines;

2. active verbs give some meaning and weight to headlines (while finite verb forms are very often omitted);

3. auxiliary verbs help to save space;

4. articles are usually omitted (unless the sense is lost);

5. widely known abbreviations should/ may be used;

6. attributions of those whose statements or comments are presented in articles should be used in headlines;

7. present tense is most common (compared to other past tenses, the past simple tense is also appropriate);

8. infinitive is often used instead of future tenses;

9. numbers should be written as numerals in order to save space;

10. punctuation should be avoided;
11. question headlines have to be replaced by direct sentences as questions refer to some uncertainty, thus, if the topic is interesting enough, question headlines might be used;

12. long words have to be replaced by short ones;

13. the most important words should be put in the beginning, etc.

\section{Meaning of Online News}

An online newspaper is the online version of a newspaper, either as a standalone publication or as the online version of a printed periodical.Going online created more opportunities for newspapers, such as competing with broadcast journalism in presenting breaking news in a more timely manner. The credibility and strong brand recognition of well-established newspapers, and the close relationships they have with advertisers, are also seen by many in the newspaper industry as strengthening their chances of survival. The movement away from the printing process can also help decrease costs.

Sajib stated 8 important things of reading newspaper in online: (http://breathing.hubpages.com/hub/8Important-Things-Of-ReadingNewspaper-In-Onlinestated)

While someone is reading a newspaper he or she is cutting a tree. Nowadays the importance of online newspaper has tremendous value. People are becoming more accustomed and used to with this type of newspapers. It has various positive aspects.

1. Online newspapers are saving our environment by reducing the use of papers. Thus we can save lot of trees from cutting down.

2. It gives us news and views as soon as any incident happens.

3. More and more people are using internet and they can easily get 
access of the online newspapers. Millions of people all over the world everyday visit the websites of online newspapers.

4. The technological advancement through all over the world worked as the catalyst for spreading on-line newspaper.

5. Climate change is accelerated by desertification and deforestation and that is prompted by cutting down trees in a large scale. If we can stop the use of wood like in newspapers then we can contribute to the protection of environment. The online version of newspaper is more eco friendly. So, the dependence of paper based newspaper should be shifted to the online version.

6. Online newspaper is also very much useful in opinion building. Usually a space or option is given in online edition of newspapers where people can easily give opinion. So, it becomes easy to assess the popular feeling or sentiment on any occasion.

7. It is cost effective too. People can save their valuable money while reading newspapers from internet.

8. It also breaks the geographical barrier. People from any place of the world can get access to the online news and views by using internet. Globalization is accelerated by it. The prospect of global village becomes reality when the newspapers are in online.

\section{Meaning of Connotation}

In addition, all languages tend to have closely related pairs of words distinguished from one another only by a single component of meaning. This component is termed as "the contrastive component" which is defined by Nida in Ahmed (2002:5) as "a semantic component which serves to distinguish one meaning from another, whether the meanings belong to one word or several."

Connotative meaning poses greater difficulty to the translator than denotative meaning because it is variable according to historical period and culture. The wider the gap between the Source Language and the Target Language cultures, the more problematic the issue of translatability becomes. Some words with neutral connotations in the SL may have strong emotional overtones in the TL if translated literally (Larson in Ahmed, 2002:4). Further, a word may have a positive connotation in one language and a negative one in another. Nevertheless, there may be various lexical choices a translator may draw based on connotative meanings. 'Mismatches' in connotation between the SL and TL lexemes result in loss in translation especially in literary texts, where any translation, as Savory explains, is but an imitation or recreation of the original; it is only a translation in the primitive sense of being a transcript of its meaning.

One should not assume, however, that denotative meaning is easier to translate than connotative meaning since it is often difficult to find denotative equivalents. This is because, languages combine meaning components differently.

\section{RESEARCH METHOD}

This research conducted qualitative method descriptively. Descriptive research, according to Gay and Airasian (2000: 275), is a study to determine and describe the way things are.

The data are collected from Jakarta Post online headline news. Literature review and relevant research have been observed to obtain the data 
description. In this case, the headlines will beemployed.It aims is not to differentiate between the mistake and error, but to find out the classification types of several categories of connotation words. There are 30 of headline news from The Jakarta Post Online News. From 30 Headline news, the writer will analysing and describing the connotation meaning from each headline.

This research conducted qualitative method descriptively.The writers do some steps in data collection. There are 30 headlines news taken from The Jakarta Online news to be analyzed. The next following steps as parts of data analysis are: 1) Reading the headline news. 2) Analysing the headlines by determining the connotation and classifying the headlines based on positive connotations and negative connotations.

\section{FINDING AND DISCUSSION}

Findings of positive connotation words in headline news online

\begin{tabular}{ccr}
\hline No & Indicator & $\begin{array}{r}\text { Average result } \\
\text { (in percentage) }\end{array}$ \\
\hline 1 & Positive & $\frac{14}{30} \times 100 \%=$ \\
Connotation & $46,66 \%$ \\
\hline
\end{tabular}

All of 30 headline news found in

The Jakarta Post online, there are $46.66 \%$ positive connotations. They use positive connotation words in order wants to give a positive feeling to the readers about the object that they talked about.

Findings of negative Connotation words in headline news online

\begin{tabular}{ccr}
\hline No & Indicator & $\begin{array}{r}\text { Average result } \\
\text { (in percentage) }\end{array}$ \\
\hline 1 & Negative & $\frac{16}{30} \times 100 \%=$ \\
Connotaion & $53,33 \%$ \\
\hline
\end{tabular}

The other finding is that all of 30 headline news found in The Jakarta Post online, $53,33 \%$ of them use negative connotation words in the news. The news writers use negative word in their news in order to attrack the readers to their news. When the writer uses negative connotation word in their news it can persuade the reader and can make the reader more corious of their news. In short, it can give a good impact to the readers.

After calculating the findings of the research, the researchers try to find and make the connection between the findings and the research questions. The research questions of this research are: 1 . How is the language used in the Jakarta Post headline news online? and 2. What is the type of connotation words that dominantly arise in the Jakarta Post headline news online?

The first research question has already been answered in the finding parts point. It can be seen that there are 14 positive connotation words occured in the Jakarta Post headline news online. The author uses positive connotation words in order to give a positive feeling or, maybe, positive perspective to the readers about the subject of the news. Below are the example of positive connotation words from The Jakarta Post headline online news :

\begin{tabular}{|c|c|c|c|}
\hline $\begin{array}{l}\text { Headline } \\
\text { Online } \\
\text { News }\end{array}$ & $\begin{array}{l}\text { Connotation } \\
\text { Word(s) }\end{array}$ & $\begin{array}{c}\text { Type of } \\
\text { Connotation }\end{array}$ & Meaning \\
\hline $\begin{array}{l}\text { Neglected } \\
\text { kids in } \\
\text { safe } \\
\text { house }\end{array}$ & Neglected & $\begin{array}{c}\text { Positive } \\
\text { Connotation }\end{array}$ & $\begin{array}{l}\text { Suffering a } \\
\text { lack of } \\
\text { proper care } \\
\text { / not } \\
\text { receiving } \\
\text { proper } \\
\text { attention; } \\
\text { disregarded }\end{array}$ \\
\hline
\end{tabular}

There are also $53,33 \%$ of the headline news using negative connotation words in the headline news. 
Similar with positive connotation, the writer of headline news used negative connotation The news writers use negative word in their news in order to attrack the reader to their news. When the writer uses negative connotation word in their news it can persuade the reader and can make the reader more curious of their news. It can give a good impact to the reader. The example of negative connotation related to headline online news is presented below :

\begin{tabular}{|c|c|c|c|}
\hline $\begin{array}{c}\text { Headline } \\
\text { Online } \\
\text { News }\end{array}$ & $\begin{array}{c}\text { Connotation } \\
\text { Word(s) }\end{array}$ & $\begin{array}{c}\text { Type of } \\
\text { Connotation }\end{array}$ & Meaning \\
\hline $\begin{array}{c}\text { Jakarta's } \\
\text { low - } \\
\text { skilled } \\
\text { workers } \\
\text { on the up }\end{array}$ & Low-skilled & $\begin{array}{l}\text { Negative } \\
\text { Connotation }\end{array}$ & $\begin{array}{c}\text { Low - in } \\
\text { do } \\
\text { something } \\
\text { well } \\
\text { ( not } \\
\text { expert ) }\end{array}$ \\
\hline
\end{tabular}

\section{CONCLUSION}

This research investigated the use of connotation word in headline news online of The Jakarta Post. Firstly, this research finds out that the writer of news sometimes use connotation words in their news in order to give an impression in their news. The connotation words used can be negative connotation or positive connotation. Due to the analysis of the data in the previous chapter, it can be concluded that $46,66 \%$ of the 30 headline news online use positive connotation word in the news. And 53,33 $\%$ of the 30 headline news online use negative connotation word in the news. The news writers use negative word in their news in order to attrack the reader to their news. When the writer use negative connotation word in their news it can persuade the readers and can make the reader more curious of their news. It can give a good impact to the readers.

\section{REFERENCES}

Books:

Ahmed, M.F. (2002). The Perlocutionary Effect of Speech Acts in Quranic Legal Provisions in Existing English Translations of the Quran. Baghdad: Al Mustinsiriya University.

Anis, G.P.T (2007). Proses Penentuan Headline Surat Kabar; Studi Pada Harian Manado Post.

Bitinienè, A., (2007). Publicistinis Stilius. Vilnius: Vilniaus pedagoginio universiteto leidykla.

Craig, R., (2004). Online Journalism: Reporting, Writing and Editing for New Media. Belmont:Thomson Wadsworth.

Dor, D. (2003). Journal of Pragmatics 35; On newspaper headlines as relevance optimizers. Department of Communications: Tel Aviv University: Tel Aviv, Israel.

Gay, L. R., \& Airasian, P. (2000). Educational Research: Competencies for Analysis and Application. New Jersey: Prentice-Hall.

McNair, B., (2009). News and Journalism in the UK. New York: Taylor \& Francis.

Marcinkevičienė, R., (2008). Žanro ribos ir paribiai. Spaudos patirtys. Vilnius: Versus aureaus.

Rich, C., (2010). Writing \& Reporting News: A Coaching Method. Wadsworth: Cengage Learning.

Šipošová, A. (2011). Headlines And Subheadlines: Tense, Modality And Register Based on Discourse Analysis of the British 
Tabloid The Sun. Masaryk University: Faculty of Arts: Department of English and American Studies. English Language and Literature.

Internets:

(http://breathing.hubpages.com/hub/8Important-Things-Of-ReadingNewspaper-In-Onlinestated, diakses pada tanggal 1 April $\underline{2015)}$
(http://www.kalbos.ktu.lt/index.php/KSt ud/article/viewFile/2839/2159H eadlines of Online News Articles: Degree of Equivalence in Translation Saulè Petronienè, Indrè Žvirblytė.

(http://www.neurocog.ull.es/wpcontent/uploads/2012/04/Ecwra markus_14.pdf. diakses pada tanggal 21 April 2015 ) 